\title{
Lesbian Lives in Soviet and Post-Soviet Russia: Post-Socialism and Gendered Sexualities
}

By FRANCESCA STELLA. (Palgrave Macmillan Series on Genders and Sexualities in the Social Sciences). pp. 192. Basingtstoke and New York. Palgrave Macmillan. 2015. £60.00. Hardback. ISBN: 9781137321237.

Topics on people's non-heterosexualities are sometimes regarded as taboo, but Francesca Stella proves to be an exception in her monograph Lesbian Lives in Soviet and Post Soviet Russia: Post Socialism and Gendered Sexualities, which investigates the political complexities of Russia's shifting ideologies that shaped the everyday experiences of non heterosexual women. Her fieldwork took place in Moscow and the provincial town of Ul'ianovsk, delineating 61 cases of homosexual women in their daily lives (p. 8). Stella's utilization of empirical methods through first-hand interviews is very impressive. She demonstrates a thoroughgoing study of politicized and marginalized lesbian identities since a decade after the collapse of the Soviet Union. Stella argues that there are two contradicting forces against homosexuality in Russia. The first is a conservative agency from above, where the state wants to rebuild family structures and to reallocate women to their "natural" gender roles as a result of a demographic crisis. The second is a conservative influence from families, who attempt to coerce these lesbian women to change their orientations based on their beliefs. Stella's treatment of historical contexts in relation to lesbian experiences is engaging, however, her monograph is a deeply intricate work, dealing with complex and technical terminologies from a Foucault framework, which readers of gender studies can simply grasp while people without such knowledge will find it challenging.

Stella is a meticulous ethnographer, demonstrating her broader knowledge of postsocialist effects on homosexuals within a historical context and her in-depth expertise on the meanings of being lesbian in Russia. Her introduction assesses the translations and meanings of being queer in Russian and the idea of 'coming out' as completely different to the West. Stella argues that no liberation movements existed effectively in post-Soviet Russia and that they transformed into something more subversive than impartial (p. 22). The second chapter is broad but important for readers needing a greater historical awareness of the transition of the state's conduct towards homosexuals between the late $80 \mathrm{~s}$ and the collapse of the Soviet Union. It details important legislation leading to the decriminalization of homosexuality, such as the revoking of the 1993 Criminal Code of Male Homosexuality. However, expressions of homosexuality are generally known to be alien to Russians as a result of conservative anxieties towards a rising demographic crisis. The breakages of traditional family structures and poor parenthoods were negative reflections of social relations, particularly for "working mothers" balancing dual responsibilities at home and work. Stella's intent of using historical and sociocultural contexts helps the readers to understand why the government and conservative groups become antipathetic to homosexuals, who are perceived as disruptive to Russian traditions.

The third chapter includes some interviews with Stella's subjects, who engage in medical debates on whether being a homosexual is considered an inherent attribute or an illness that needs to be cured through a sexopathologist. This "demedicalization" is examined through a Foucault theory that sexuality is something socially constructed due to ideological changes, and in Russia's case this was the abrupt shift towards market capitalism. For the new post-socialist state, the demedicalization is fundamental to reeducation of homosexuals (p. 48). Chapters Four and Five are acclaimed for how the author presents her findings through an empirical approach. Several cases have proven how lesbian individuals grow estranged from particular communities and workplaces that contravene their sexual orientations. The sections about family are intriguing because home is a symbol of security and comfort, but for most Russian lesbians, the violence and alienation from their loved 
ones are more forceful than at the workplace or on the public streets. The author particularly highlights that citizens of Ul'ianovsk are more sensitive to homosexuality than in Moscow because of its isolated conditions (p. 101). Chapter Seven compares the experiences in both cities and provides a deeper understanding of identity politics, showing that homosexuals are torn between choosing to belong to or resist their country, where most people are antipathetic against the idea of homosexuality rather than the individual.

This work is neither simply a reflection or a critique. Rather, Stella suggests that the readers themselves engage in debate, which is why her work dominantly uses an empirical over theoretical approach. My main criticism is that the introduction is quite long and ought to be more concise, however, Stella's work is a valuable contribution for scholars studying gender studies. It is a well-founded publication because she has conducted first hand interviews with lesbians and analyzed her findings methodologically. Some terminologies are difficult to grasp, nevertheless, Stella raises startling issues of the lesbians' everyday experiences of compromising their behaviours in both private and public spaces. Stella's claim of their anachronistic nature in post-socialist Russia is telling about society itself, that only if influential conservativeness declines will homosexuality be able to be reconciled with both government and family life.

VIVIAN SABRINA LEE

School of Slavonic and East European Studies

University College London

This work is licensed under the Creative Commons Attribution 4.0 International License. This license lets others distribute, remix, tweak, and build upon the author's work, even commercially, as long as they credit the author for the original creation. To view a copy of this license, visit bttp:/ / creativecommons.org/licenses/by/4.0/. 